\title{
Experimental study of the influence of friction at the supports on longitudinal shear resistance of composite slabs
}

\section{Estudo experimental da influência do atrito nos apoios na resistência longitudinal ao cisalhamento das lajes mistas}

R. S . COSTA a

rsernizon@dees.ufmg.br

A. C. C. LAVALL a

lavall@dees.ufmg.br

R. G. L. SILVA rglanna.silva@gmail.com

F. C. RODRIGUES a

francisco@dees.ufmg.br

\begin{abstract}
The aim of this work is to evaluate the behavior and strength of composite slabs considering the influence of the friction at the sheeting-concrete interface in the region of the support. Results from tests conducted in the Structural Engineering Department of Federal University of Minas Gerais (UFMG) were used. A Steel Deck 60 system was considered, which consists of a trapezoidal profile with "V" shaped embossments. Deflections, end slips and strains of the steel decks were measured, allowing for the analysis of the behavior of the composite slab system and for the determination of its failure mode. The influence of friction of the region of support in the longitudinal shear resistance was evaluated through the partial shear connection method, which also allowed for establishing criteria and determination of analytical expressions for calculating the ultimate load. Comparative analyses reveal that the influence of the friction of the region of support in the shear-bond resistance is more significant in composite slabs with short shear spans. Design expressions which incorporate friction will also be presented. Their application have demonstrated the efficiency of the method for evaluating the longitudinal shear resistance.
\end{abstract}

Keywords: composite slabs, partial shear connection, friction at the support.

\section{Resumo}

O objetivo deste trabalho é avaliar o comportamento e a resistência de um sistema de lajes mistas de aço e concreto, considerando a influência do atrito na interface da fôrma de aço com o concreto na região dos apoios. Para isso foram utilizados os resultados de ensaios realizados no Departamento de Engenharia de Estruturas da Universidade Federal de Minas Gerais (UFMG). O sistema misto Steel Deck 60 foi considerado, o qual consiste em um perfil trapezoidal com mossas em forma de "V". As flechas, os deslizamentos de extremidades e as deformações das fôrmas de aço foram medidos, permitindo a análise do comportamento do sistema de laje mista e a determinação do seu modo de falha. A influência do atrito da região dos apoios na resistência longitudinal ao cisalhamento foi avaliada através do método da interação parcial, que também permitiu estabelecer critérios visando à determinação de expressões analíticas para o cálculo da carga última. As análises comparativas revelaram que a influência do atrito da região dos apoios na resistência ao cisalhamento longitudinal é mais significativa em lajes mistas com pequenos vãos de cisalhamento. São apresentadas expressões de cálculo incorporando o atrito, cujas aplicações em um exemplo permitiram mostrar a eficiência do método no cálculo da resistência ao cisalhamento longitudinal.

Palavras-chave: laje mista de aço e concreto, método da interação parcial, atrito nos apoios. 


\section{Introduction}

The use of a system of composite slabs of concrete and steel in metal construction began in the 1930s, according to Veljkovic'[1]. In these systems, the slabs have steel sheeting with very thin thickness, usually between $0.80 \mathrm{~mm}$ and $1.25 \mathrm{~mm}$, embedded in the system that work as permanent steel sheeting, supporting the concrete before curing and construction loads. After curing, the concrete and the steel sheeting become bonded, forming a single structural composite element. The steel deck works as positive reinforcement for the composite slab.

Currently, composite slab systems have become a widely used method for the construction of slabs in buildings in steel structures. From the structural behavior standpoint, the profiled steel sheeting is capable of transmitting the longitudinal shear at the interface between the stee sheeting and the concrete. Composite behavior between profiled sheeting and concrete is ensured by the mechanical interlock provided by deformations in the profile (indentations or embossments), by the frictional interlock for profiles shaped in a re-entrant form, by the end anchorage provided by welded studs or another type of local connec- tion between the concrete and the steel sheet, by the end anchorage from the deformation of the ribs at the end of the sheeting and by the friction in the region of the support. If there is no mechanical link or an attachment by friction between the sheeting and concrete, it will not be able to transmit longitudinal shear, and thus, the composite slab action will not be effective.

The main objective of this study is to analyze, after curing the concrete, the influence of friction of the region of support in the longitudinal shear resistance of the composite slab system Deck- 60, using the partial shear connection method.

\section{Characteristics of the test specimens}

To conduct the analysis using the partial shear connection method and considering the friction at the supports, a series of twelve specimens of simply supported composite slabs were tested in bending. Figure 1 shows a typical cross-section profile of the Deck-60 with the "V-shape" embossments that were pressed onto the webs and its nominal dimensions in millimeters.

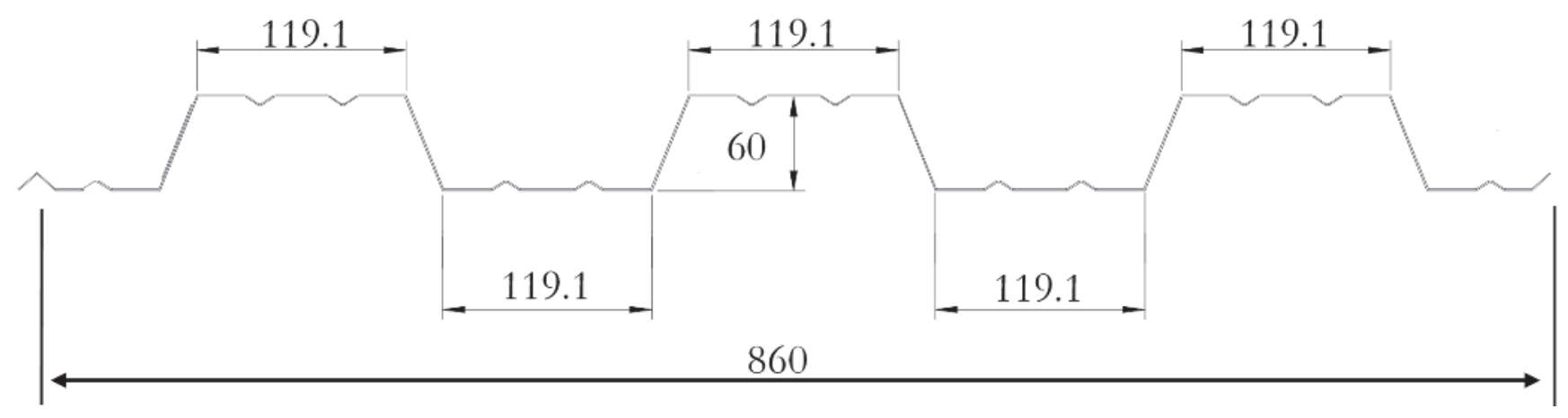

Figure 1

Cross-section of the steel deck

Table 1

Geometrical characteristics of test specimens

\begin{tabular}{|c|c|c|c|c|c|}
\hline Specimens & $\begin{array}{c}\mathbf{t} \\
(\mathbf{m m})\end{array}$ & $\begin{array}{c}\mathbf{b} \\
(\mathbf{m m})\end{array}$ & $\begin{array}{c}\mathbf{L} \\
(\mathbf{m m})\end{array}$ & $\begin{array}{c}\mathbf{h}_{\mathbf{t}} \\
(\mathbf{m m})\end{array}$ & $\begin{array}{c}\mathbf{L}_{\mathbf{s}} \\
(\mathbf{m m})\end{array}$ \\
\hline 01A & 0.80 & 860 & 2500 & 110 & 800 \\
\hline 01B & 0.80 & 860 & 2500 & 110 & 800 \\
\hline 01C & 0.80 & 860 & 2500 & 110 & 800 \\
\hline 02A & 0.80 & 860 & 2500 & 140 & 450 \\
\hline O2B & 0.80 & 860 & 2500 & 140 & 450 \\
\hline 02C & 0.80 & 860 & 2500 & 140 & 450 \\
\hline 03A & 0.95 & 860 & 2500 & 110 & 800 \\
\hline 03B & 0.95 & 860 & 2500 & 110 & 800 \\
\hline 03C & 0.95 & 860 & 2500 & 110 & 800 \\
\hline 04A & 0.95 & 860 & 2500 & 140 & 450 \\
\hline O4B & 0.95 & 860 & 2500 & 140 & 450 \\
\hline 04C & 0.95 & 860 & 2500 & 140 & 450 \\
\hline
\end{tabular}




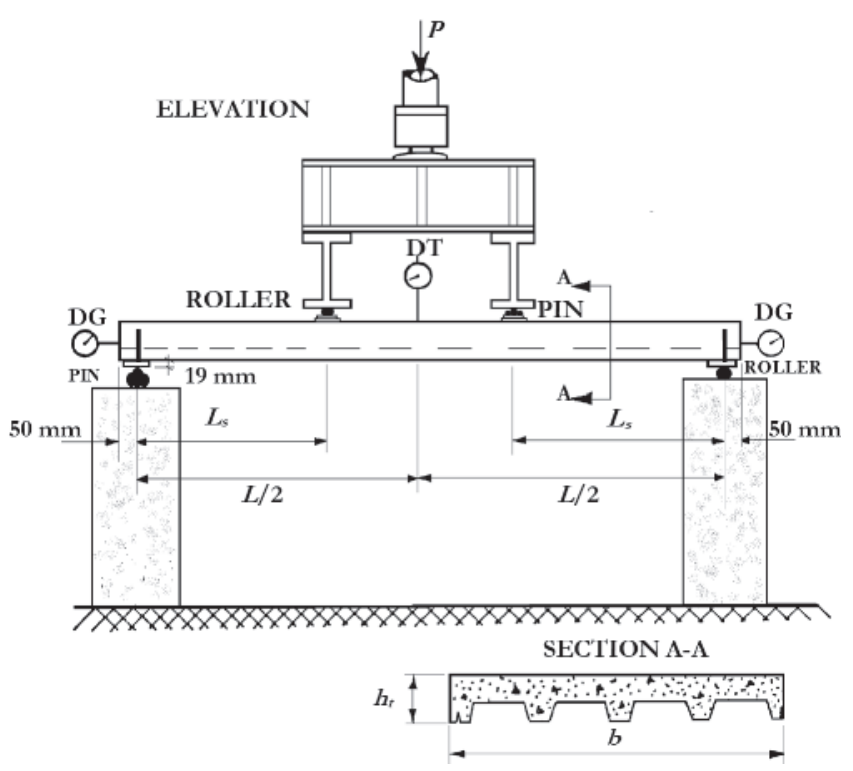

Figure 2

Typical test set-up

Table 1 shows the geometrical properties of the specimens that were divided into two groups: six specimens with a nominal thickness of the steel profile t equal to $0.80 \mathrm{~mm}$ and six with thickness $\mathrm{t}$ of $0.95 \mathrm{~mm}$, with a nominal width of the profile b equal to $860 \mathrm{~mm}$ and length $L$ equal to $2500 \mathrm{~mm}$. In each group, three specimens were built with depth $h_{t}$ of $110 \mathrm{~mm}$ and a span shear $L_{s}$ of $800 \mathrm{~mm}$, and the other three were built with depth $h_{t}$ of $140 \mathrm{~mm}$ and span shear $\mathrm{L}_{\mathrm{s}}$ of $450 \mathrm{~mm}$.

The steel decking with thickness $t$ equal to $0.80 \mathrm{~mm}$ was made with ZAR 280 steel with yield strength $\left(f_{y}\right)$ equal to $340 \mathrm{MPa}$ and ultimate tensile strength $\left(f_{u}\right)$ equal to $450 \mathrm{MPa}$. The steel decking with thickness equal to $0.95 \mathrm{~mm}$ was made with ZAR 345 steel with $f_{y}$ equal to $390 \mathrm{MPa}$ and $f_{u}$ equal to $490 \mathrm{MPa}$. The modulus of elasticity of structural steel, $E_{a}$, was taken equal to $200 \mathrm{GPa}$, and the 28-day compressive strength of concrete, $f_{c k}$ was $20 \mathrm{MPa}$.

\section{Test procedure}

Each specimen was subjected to four points bending test, as shown in Figure 2. This system of load application is similar to those indicated by Schuster [2], ANSI / ASCE 3 [3], EUROCODE 4 [4], CSSBI S2 [5] and Johnson and Shepherd [6].

Vertical deflections at midspan were measured by two displacement transducers (DT) with a maximum range of $100 \mathrm{~mm}$, symmetrically arranged at approximately $20 \mathrm{~cm}$ from the edge of the slab. The end-slip between the steel decking and the concrete was recorded through two digital dial gauges (DG) attached at the ends of each specimen, two on each side.

Two electrical resistance strain gauges (EER) were applied to all specimens to measure steel strain. These EER were installed in the midspan, using cyanoacrylate adhesive, one on the lower fiber and another on the upper fiber of the steel decking, as shown in Figure 3.

Loads were monotonically applied in steps of $1.8 \mathrm{kN}$ and strains,

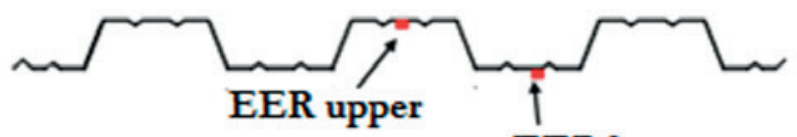

EER lower

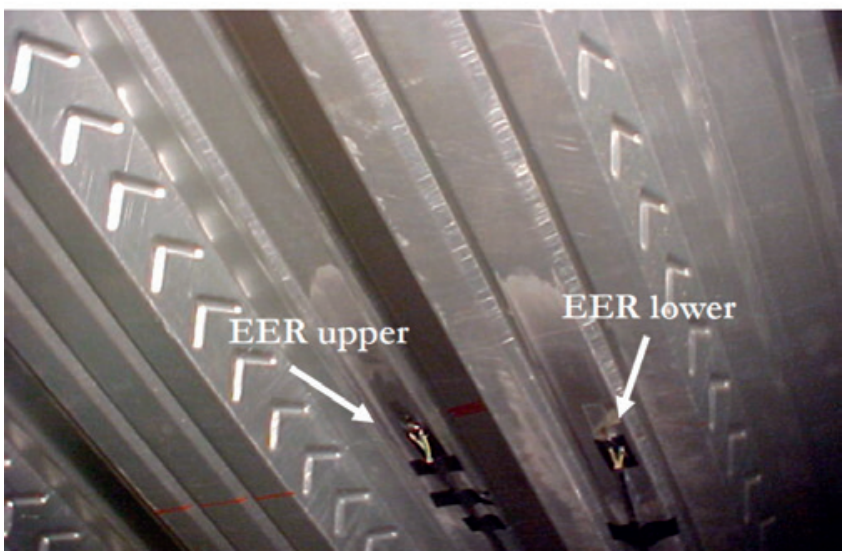

Figure 3

Location of strain gauges (EER) on the steel deck

deflections and end-slips were measured at each load level. Cracking patterns, end-slip and the ultimate load of each specimen were recorded.

\subsection{Test results and analysis}

The analysis of the test results and a general description of behavior of the composite slabs are studied through load versus end-slip, load versus midspan deflection and load versus steel strain relationships. The specimen $01 \mathrm{~A}$ was chosen as representative of all tests, to illustrate the following comments.

Figure 4 shows the load versus end-slip curves of the specimen 01A. Initially the horizontal slip is almost absent, indicating a full shear connection between the sheeting and the concrete. After the first cracks, the chemical bond between the sheeting and the concrete is broken, causing end-slip, indicating partial connection.

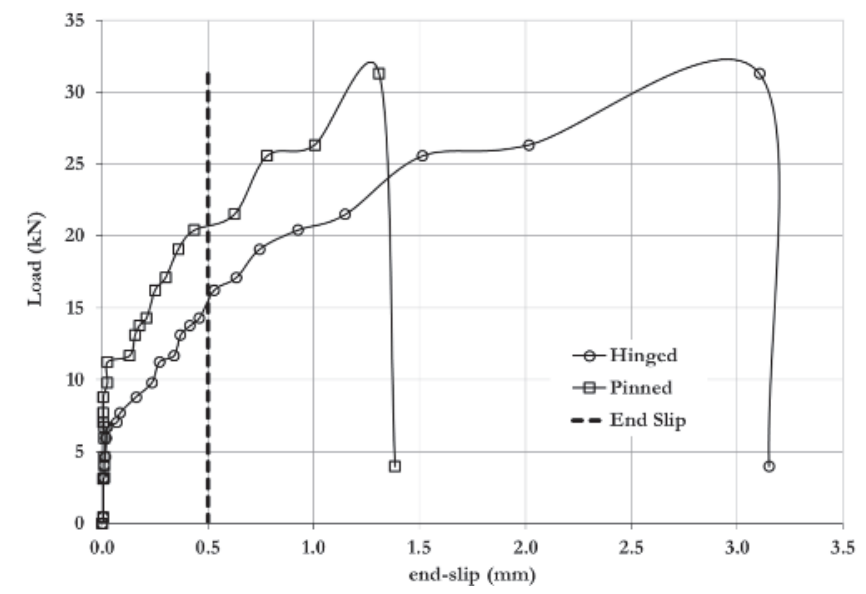

Figure 4

Load versus end-slip of the specimen $01 \mathrm{~A}$ 
Table 2

End-slip loads and maximum loads of tests

\begin{tabular}{|c|c|c|c|}
\hline Specimens & $\begin{array}{c}\mathbf{P}_{\mathbf{u}} \\
(\mathbf{N})\end{array}$ & $\begin{array}{c}\mathbf{P}_{\text {des }} \\
(\mathbf{N})\end{array}$ & $\mathbf{P}_{\mathbf{u}} / \mathbf{P}_{\text {des }}$ \\
\hline 01A & 32170 & 16200 & 1.99 \\
\hline 01B & 33710 & 16230 & 2.08 \\
\hline 01C & 32720 & 16750 & 1.95 \\
\hline 02A & 57170 & 43950 & 1.30 \\
\hline 02B & 56290 & 34480 & 1.63 \\
\hline 02C & 63450 & 28420 & 2.23 \\
\hline O3A & 39621 & 20490 & 1.93 \\
\hline 03B & 39837 & 21810 & 1.83 \\
\hline O3C & 36701 & 20830 & 1.76 \\
\hline 04A & 68443 & 32060 & 2.14 \\
\hline 04B & 71354 & 30250 & 2.36 \\
\hline 04C & 77508 & 28810 & 2.69 \\
\hline
\end{tabular}

According to EUROCODE 4 [4], the initial end-slip load $\left(P_{\text {des }}\right)$ is defined as the load that causes an end-slip of $0.5 \mathrm{~mm}$ between the sheeting and the concrete. The longitudinal shear behavior is considered ductile if the failure load $\left(P_{u}\right)$ exceeds the initial end-slip load $\left(P_{\text {des }}\right)$ by more than $10 \%$. Table 2 shows end-slip and failure loads for all specimens.

Figure 5 shows the load versus midspan deflection curve of the specimen 01A. Two stages in the load-deflection behavior were identified: uncracked and cracked stages.

In the first stage, no visible cracking was observed anywhere on the specimen, hence, the entire section remained fully composite up to the initial cracks. The cracked stage was identified by the first significant change in initial stiffness of each specimen that occurred with the appearance of the initial cracks (the loaddeflection curve ceases to be linearly proportional). Without the presence of shear transfer devices (embossments and friction),

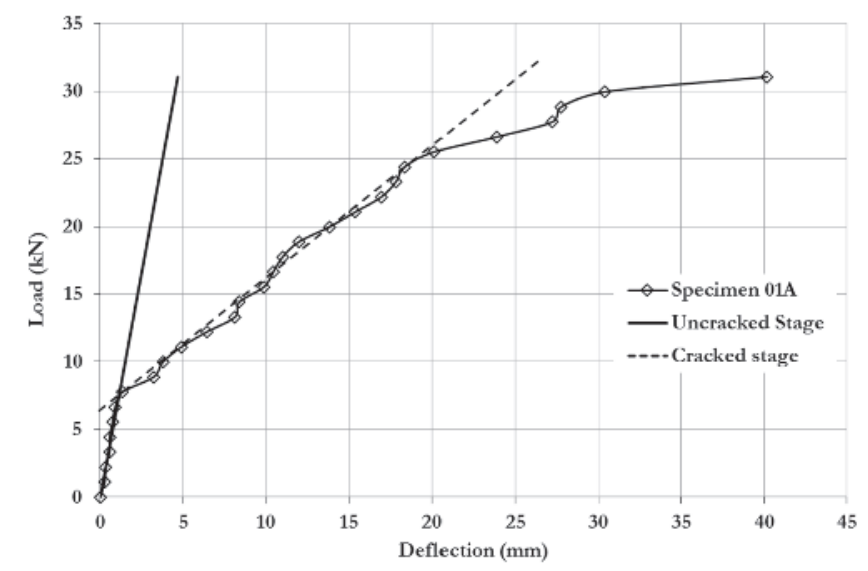

Figure 5

Load versus midspan deflection of the specimen $01 \mathrm{~A}$

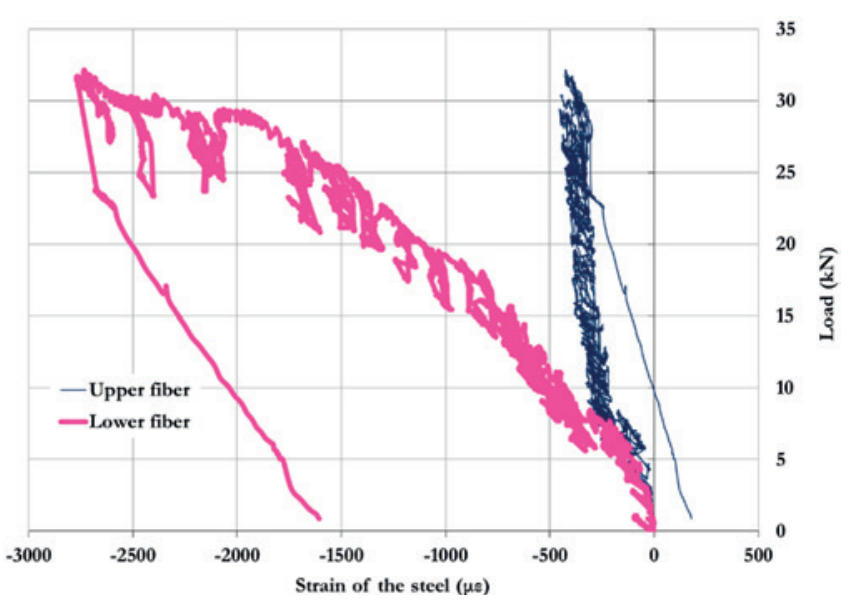

Figure 6

Load versus steel strain curves for specimen 01A

the specimen would not be able to support any additional load beyond this load stage.

Figure 6 shows the load versus steel strains curve for specimen 01A, where negative values indicate tensile strains. During the uncracked stage, a linearly proportional increase of the tensile strains occurs in the sheeting in both the lower and higher fibers, indicating the existence of a single neutral axis in the concrete. The tensile strains in the top fiber of the sheeting decrease after the initial crackings, indicating the presence of two neutral axes in the composite section, indicating partial shear connection between the steel sheeting and the concrete. Based on the experimental results of this investigation, only one mode of failure was experienced by the composite slab system, namely, longitudinal shear. This ultimate limit state is characterized by the shear failure of the connection between the embossments of steel sheeting and the concrete, in the region of the shear span, $L_{s}$, where the concrete looses the composite action with the steel sheeting. This failure is indicated by an end-slip between the steel sheeting and the concrete, as shown in Figure 7. This behavior has been observed by Schuster [2], Wright et al. [7], Tenhovuori and Leskela [8], Melo [9], Marimuthu et al. [10], Cifuentes [11] and other authors.

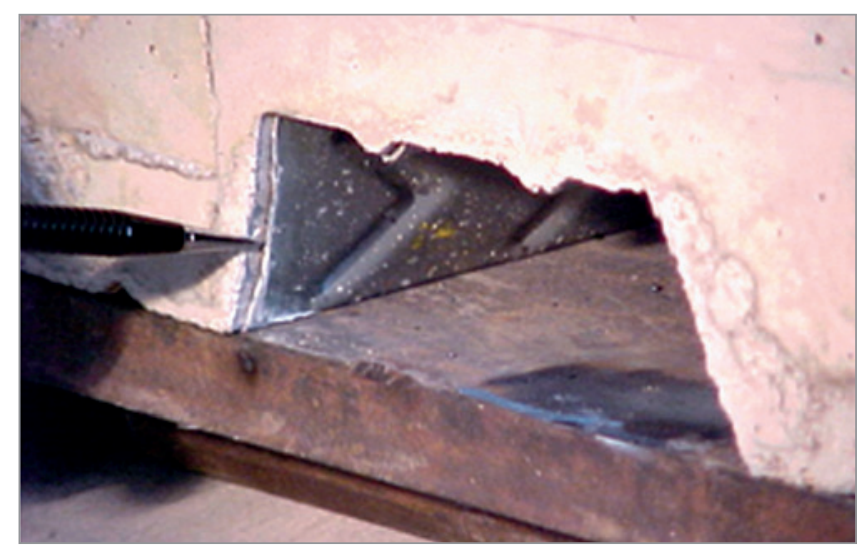

Figure 7

End-slip between the steel sheeting and the concrete 


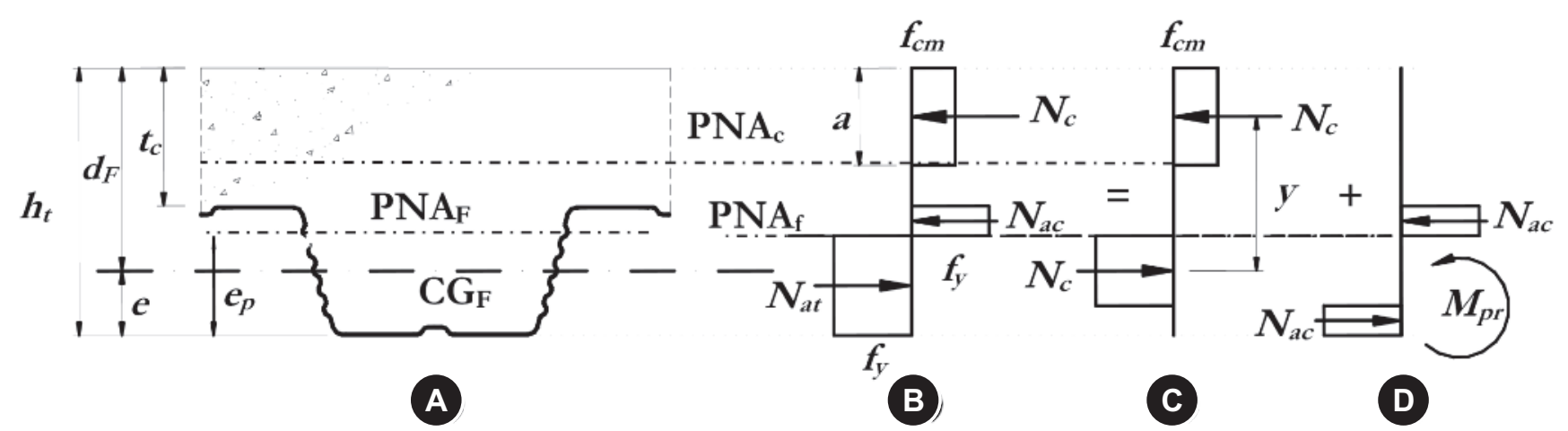

Figure 8

Normal stress distribution for sagging bending, considering the partial interaction

\section{Partial shear connection method}

According to EUROCODE 4 [4], two methods are used in the design of composite slabs: the " $\mathrm{m}$ - $\mathrm{k}$ " method and the Partial Shear Connection (PSC) method. Both methods are based on experimental results with full-scale specimens. Depending on the test results, the behavior of a slab might be classified as brittle or ductile. The " $m-k$ " method can be used for all profiles, whereas the PSC method can be used only for ductile profiles. In addition, according to Johnson [12], the PSC method evaluates, theoretically, the contribution of the end anchorage and of the friction of support in the longitudinal shear strength.

\subsection{Analytical model}

The PSC method is based on an analytical model with a physical background, and it basic concepts are illustrated in Figure 8. The model can be better understood by examining the typical module of the composite slab cross section, as shown in Figure 8(a). The normal stress distribution considering the partial interaction has two neutral-plastic axis: one in the concrete $\left(\mathrm{PNA}_{\mathrm{c}}\right)$ and other in the steel sheeting $\left(\mathrm{PNA}_{\mathrm{f}}\right)$, as shown in Figure $8(\mathrm{~b})$. This distribution can be decomposed, by simplification, from the diagrams shown in the Figures 8(c) and 8(d).

Figure 8(a) shows that $h_{t}$ is the overall depth of the slab; $e$ is the distance from the centroidal axis of profiled steel sheeting to bottom of the steel deck; $d_{F}$ is the distance from the centroidal axis of the profiled steel sheeting to the top of the composite slab; $e_{p}$ is the distance from the neutral-plastic axis of the profiled steel sheeting to the bottom of the steel deck; $t_{c}$ is the thickness of the concrete above the flat surface of the top of ribs of the steel sheeting.

As shown in Figure $8(\mathrm{~b}), f_{y}$ is the nominal value of the yield strength of the structural steel, where for the nominal thicknesses of $0.80 \mathrm{~mm}$ and $0.95 \mathrm{~mm}, f_{y}$ equal to $340 \mathrm{MPa}$ and $390 \mathrm{MPa}$, respectively $f_{c m}$ is the mean value of the compressive strength of the concrete; $a$ is the depth of the concrete block in compression; $N_{a t}$ is the tensile normal force in the steel sheeting; $N_{c}$ is the compressive normal force in the concrete flange; $N_{a c}$ is the compressive normal force in the steel sheeting. In Figure 8(c), $y$ is the lever arm in the typical module of the composite slab; $N_{a}$ is the difference between $N_{a t}$ and $N_{a c}$ corresponding to a portion of the tensile normal force in the steel sheeting.

The bending resistance, $M_{R p}$, is given by the following equation:

$M_{R p}=N_{c} y+M_{p r}$

where $M_{p r}$ is the reduced plastic resistance moment of the profiled steel sheeting (see Figure 8(d)), as given by Eq. (2). This reduction is due to the presence of the tensile normal force in the steel sheeting, $N_{a}$ equal to $N_{c}$.

$M_{p r}=1.25 M_{p a}\left(1-\frac{N_{c}}{A_{F, e f} f_{y}}\right) \leq M_{p a}$

where $M_{p a}$ is the design value of the plastic resistance moment of the effective cross-section of the profiled steel sheeting, and $A_{F, e f}$ is the effective cross-sectional area of the profiled steel sheeting. The depth of the concrete block in compression, $a$, is given by:

$a=\frac{N_{c}}{b f_{c m}} \leq t_{c}$

The lever arm, $y$, may be determined with the following expression:

$y=h_{t}-0.5 a-e_{p}+\left(e_{p}-e\right) \frac{N_{c}}{A_{F, e f} f_{y}}$

\subsection{Determination of longitudinal shear resistance considering the friction at the supports}

Studies conducted by Veljcovic' [13], Tenhovuori [14], Calixto and Lavall [15], Melo [9] and Souza Neto [16] have demonstrated that in models with shear span relatively short, the influence of the friction at the supports is relevant in the determination of the longitudinal shear resistance, whereas for models with long shear span, that effect is reduced.

The friction force, $F_{f}$ is caused by the vertical reaction at the support and appears concentrated at the interface of the steel sheeting with the concrete, as illustrated in Figure 9. This effect may be considered, according to Bode and Minas [17] and other researchers, proportional to the reaction of support, $V_{u t}$ :

$F_{f}=\mu V_{u t}$

where $\mu$ is the friction coefficient. 


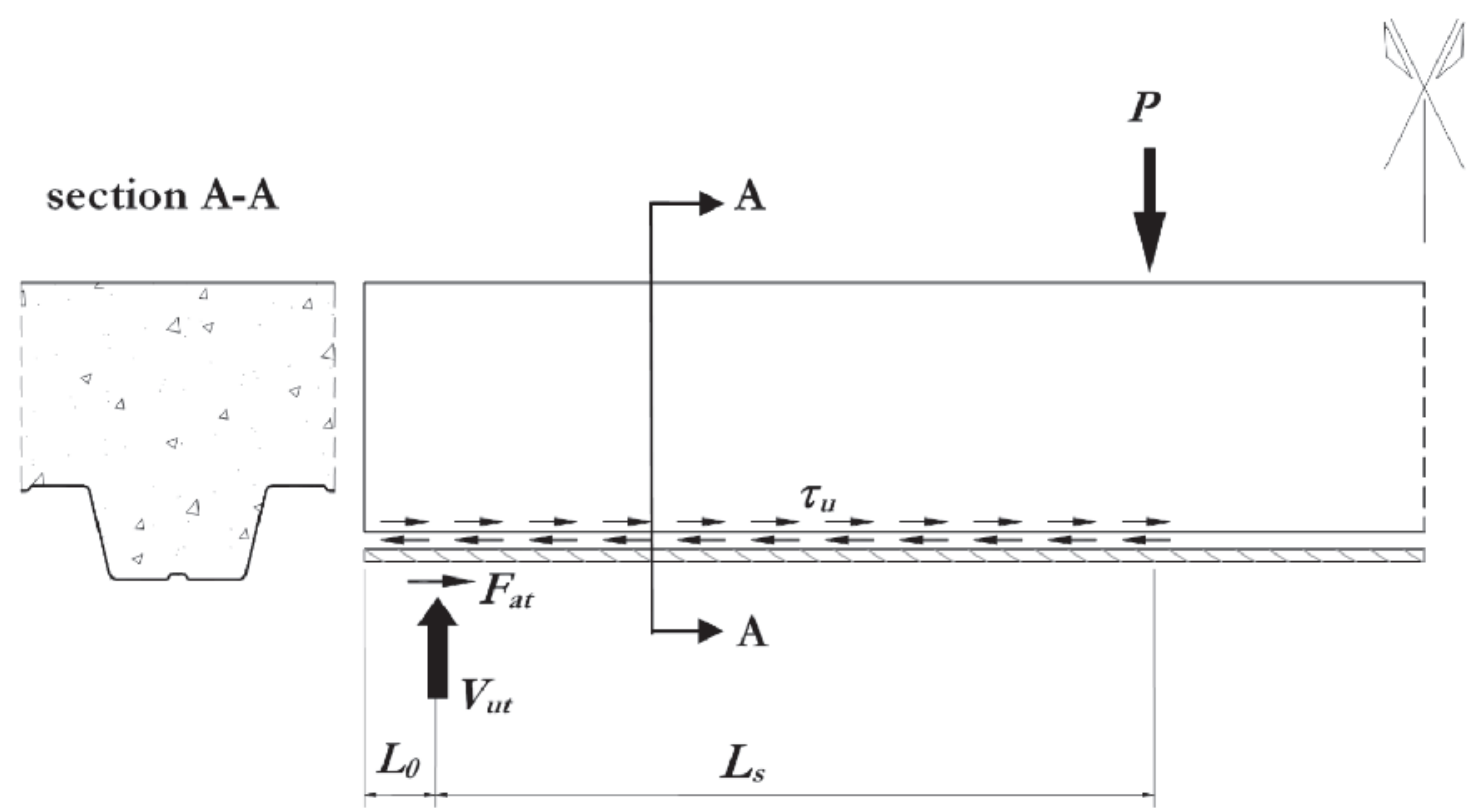

\section{Figure 9}

Friction force in the region of support at the interface of composite slab

\subsection{Degree of shear connection}

To determine the longitudinal shear strength, the partial interaction diagram of each specimen, as illustrated in Figure 10, showing relationship between the resistance to bending moment and the degree of shear connection of the composite slab, should be determined using the measured dimensions and strengths of the concrete and the steel sheet.

From the maximum applied loads, the bending moment $\left(M_{\text {test }}\right)$, at the cross-section under the point load, due to the applied load, dead weight of the slab and spreader beams, should be determined and then divided by the bending moment resistance of the slab consider-

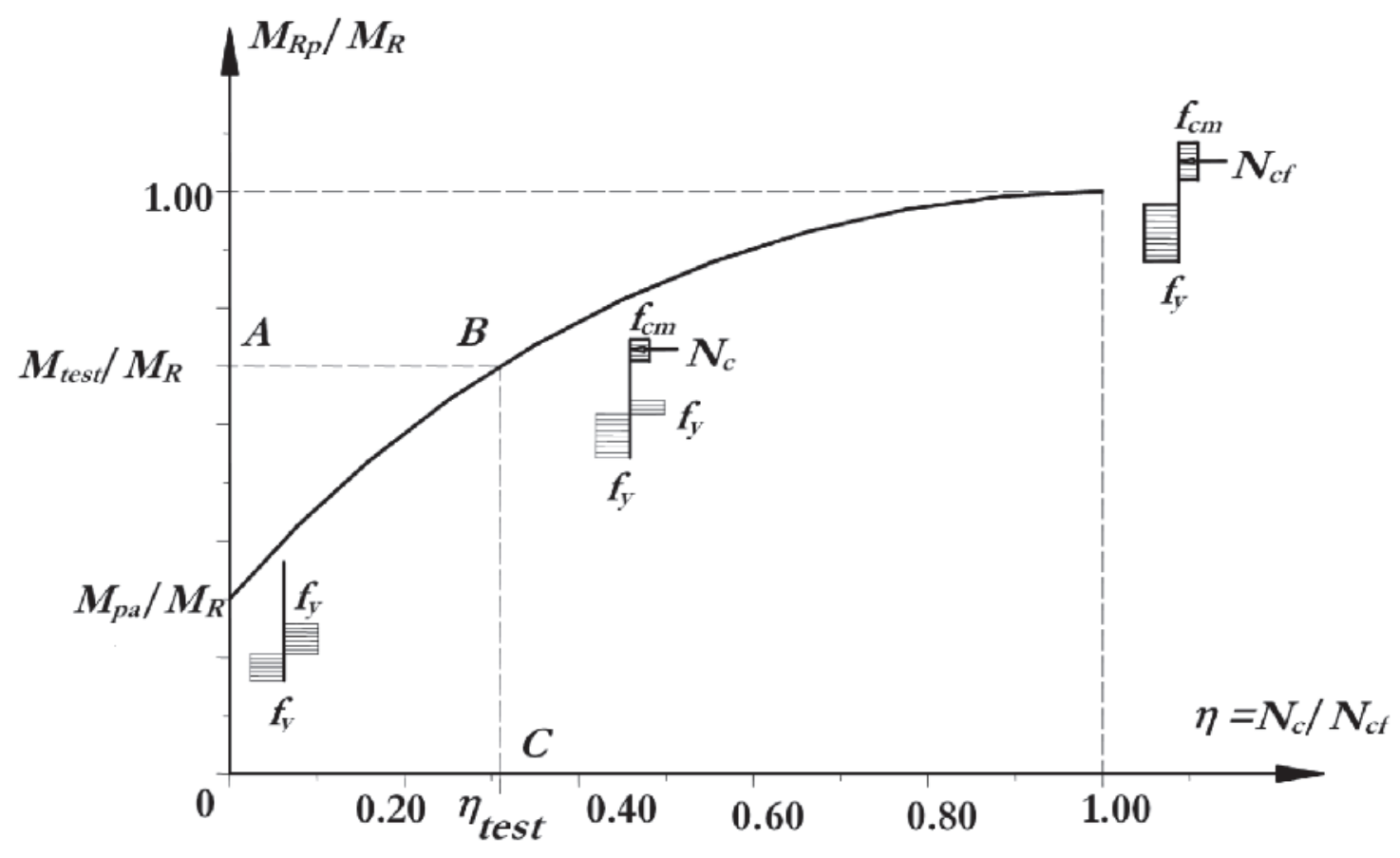

Figure 10

Determination of the degree of shear connection from $M$ test 
ing the full connection, $M_{R^{*}}$. The path $\mathrm{A} \Rightarrow \mathrm{B} \Rightarrow \mathrm{C}$ in Figure 10 gives the degree of shear connection, $\eta_{\text {test }}$ given by the ratio between $N_{c}$ and $N_{c f}$ for each specimen, where $N_{c f}$ is the value of the compressive normal force in the concrete with full shear connection.

After determining the value of $\eta_{\text {test }}$, the compressive normal force in the concrete, $N_{c}$, is given by the following equation:

$N_{c}=\eta_{\text {test }} N_{c f}$

On the other hand, the degree of shear connection ( $\eta$ ) can be determined analytically by equating the $M_{\text {test }}$ given by Eq. (7), with the nominal moment resistance $\left(M_{R p}\right)$ given by Eq. (1). Thus, we obtain the following equation:

$M_{\text {test }}=V_{u t} L_{s}-\frac{p p_{\text {slab }} L_{s}^{2}}{2}$

$M_{\text {test }}=M_{R p}=N_{c} y+M_{p r}$

The parameters $N_{c}, y$ and $M_{p r}$ are given by the Eq. (6), (4) and (2), respectively. With the aid of Eq. (3) and replacements into Eq. (8), we obtain the following equation:

$M_{\text {test }}=\eta N_{c f}\left[h_{t}-\frac{0.5 \eta N_{c f}}{b f_{c m}}-e_{p}+\left(e_{p}-e\right) \frac{\eta N_{c f}}{N_{p a}}\right]+$

$1.25 M_{p a}\left(1-\frac{\eta N_{c f}}{N_{p a}}\right)$

Developing Eq. (9) in the context of the two equations derived from Eq. (2) and knowing that $N_{c f}$ equal to $N_{p a}$ [Eq. (10)], we obtain Eq. (11):

$N_{p a}=A_{F, e f} f_{y}$

For $\eta \geq 0.20$,

$M_{t e s t}=\eta^{2} N_{c f}^{2}\left(\frac{e_{p}-e}{N_{p a}}-\frac{0.5}{b f_{c m}}\right)+$

$\eta N_{c f}\left(h_{t}-e_{p}-\frac{1.25 M_{p a}}{N_{p a}}\right)+1.25 M_{p a}$

Eq. (11) is a quadratic equation, having the degree of shear connection $(\eta)$ as unknown. This equation can be written as follows:

$i \eta^{2}+j \eta+k=0$

where

$i=N_{c f}^{2}\left(\frac{e_{p}-e}{N_{p a}}-\frac{0.5}{b f_{c m}}\right)$

$j=N_{c f}\left(h_{t}-e_{p}-\frac{1.25 M_{p a}}{N_{p a}}\right)$

$k=1.25 M_{p a}-M_{\text {test }}$

For $\eta<0.20$

$M_{t e s t}=\eta^{2} N_{c f}^{2}\left(\frac{e_{p}-e}{N_{p a}}-\frac{0.5}{b f_{c m}}\right)+\eta N_{c f}\left(h_{t}-e_{p}\right)+M_{p a}$

Eq. (16) is also a quadratic equation in $\eta$. Thus, Eq. (12) is used again where the constants are:

$j=N_{c f}\left(h_{t}-e_{p}\right)$

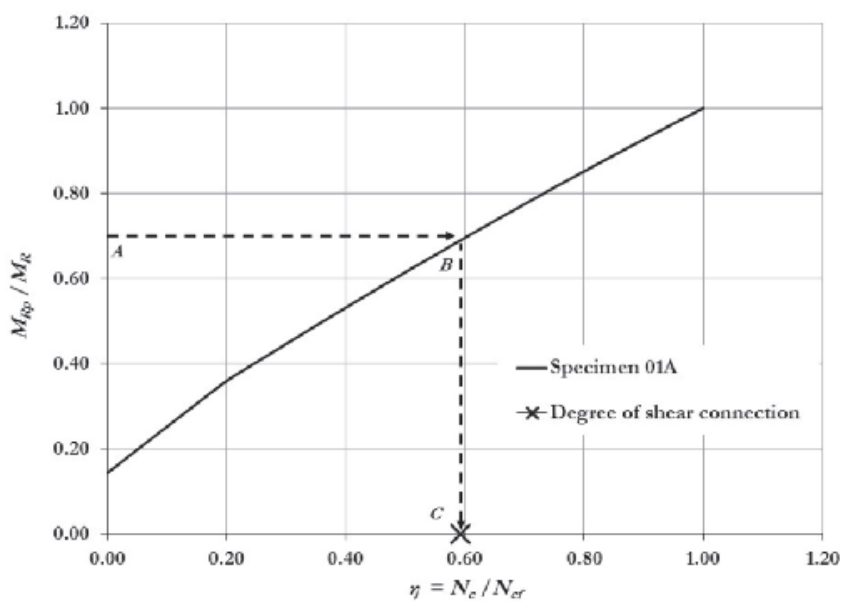

Figure 11

Partial interaction diagram and degree of shear connection $\eta$ test

$k=M_{p a}-M_{\text {test }}$

The constant $i$ is calculated by Eq. (13).

The positive root of $\eta$, smaller than 1.0, which satisfies Eq. (12), is the searched value of the degree of shear connection $\left(\eta_{\text {test }}\right)$. This value should be calculated for each specimen of composite slab. Figure 11 shows the partial interaction diagram and the degree of shear connection $\left(\eta_{\text {test }}\right)$ for the specimen 01A, using the analytical expressions.

\subsection{Longitudinal shear strength}

The value of the longitudinal shear strength of a composite slab, $T_{u}$, considering the friction of support for each specimen is assumed uniform along the length $\left(L_{s}+L_{0}\right)$, and its value is determined using the width of slab $(b)$, using the following equation:

$\tau_{u}=\frac{N_{c}-\mu V_{u t}}{b\left(L_{s}+L_{0}\right)}$

where $V_{u t}$ is the support reaction under the ultimate load test, and $L_{0}$ is the length of overhang $\left(L_{0}=50 \mathrm{~mm}\right)$.

The characteristic value of longitudinal shear strength, $\tau_{u, R k}$, should be calculated as the $5 \%$ fractile using an appropriate statistical model, in accordance with EUROCODE 0 [18], Annex D. In this work $t$-distribution was adopted:

$\tau_{u, R k}=\tau_{u, m}-t s$

where $\tau_{u, m}$ is the mean value of the longitudinal shear strength of a composite slab determined from testing; $t$ is the reliability coefficient of $t$-distribution; $s$ is the standard deviation of the longitudinal shear strength.

In Table 3, the characteristic values of the longitudinal shear strength $\left(\tau_{u, R k}\right)$ are determined according to Eq. (20).

In this table, the following are shown: the degree of shear connection of each specimen tested $\left(\eta_{\text {test }}\right)$; the value of the compressive normal force in the concrete $\left(N_{c}\right)$, given by Eq. (6), where the values of $N_{c f}$ were calculated by the Eq. (10); the friction coefficient $\mu$ 
Experimental study of the influence of friction at the supports on longitudinal shear resistance of composite slabs

Table 3

Determination of the characteristic value of longitudinal shear strength $\left(\tau_{u^{\prime}}, R_{k}\right)$

\begin{tabular}{|c|c|c|c|c|c|c|c|c|}
\hline Specimens & $\eta_{\text {test }}$ & $\begin{array}{l}\mathrm{N}_{\mathrm{c}} \\
\text { (N) }\end{array}$ & $\mu$ & $\begin{array}{l}\mathrm{V}_{\mathrm{ut}} \\
(\mathrm{N})\end{array}$ & $\begin{array}{c}\tau_{u} \\
(\mathrm{MPa})\end{array}$ & $\begin{array}{c}\tau_{u, m} \\
(\mathrm{MPa})\end{array}$ & s & $\begin{array}{c}\tau_{\mathrm{u}, \mathrm{Rk}} \\
(\mathrm{MPa})\end{array}$ \\
\hline $01 \mathrm{~A}$ & 0.592 & 183474 & \multirow{12}{*}{0.50} & 20109 & 0.2383 & \multirow{6}{*}{0.2407} & \multirow{6}{*}{0.0177} & \multirow{6}{*}{0.2050} \\
\hline $01 \mathrm{~B}$ & 0.619 & 191904 & & 20873 & 0.2503 & & & \\
\hline $01 \mathrm{C}$ & 0.604 & 187237 & & 20385 & 0.2430 & & & \\
\hline $02 \mathrm{~A}$ & 0.357 & 110716 & & 33405 & 0.2179 & & & \\
\hline O2B & 0.344 & 106713 & & 32959 & 0.2100 & & & \\
\hline $02 \mathrm{C}$ & 0.396 & 122687 & & 36534 & 0.2434 & & & \\
\hline $03 \mathrm{~A}$ & 0.528 & 224689 & & 23864 & 0.2910 & \multirow{6}{*}{0.2696} & \multirow{6}{*}{0.0214} & \multirow{6}{*}{0.2265} \\
\hline O3B & 0.488 & 207877 & & 23975 & 0.2677 & & & \\
\hline $03 \mathrm{C}$ & 0.456 & 194042 & & 22399 & 0.2507 & & & \\
\hline $04 \mathrm{~A}$ & 0.298 & 126809 & & 39066 & 0.2485 & & & \\
\hline O4B & 0.322 & 137110 & & 40511 & 0.2715 & & & \\
\hline $04 \mathrm{C}$ & 0.355 & 151122 & & 43586 & 0.3015 & & & \\
\hline
\end{tabular}

equal to 0.50 , adopted in accordance with EUROCODE 4 [4]; the support reactions $\left(V_{u t}\right)$ obtained in the tests; the longitudinal shear strength $\left(T_{u}\right)$ for each specimen given by Eq. (19); $T_{u, m}$ for each thickness of the decking and the standard deviation (s). A reliability coefficient of $t$-distribution $t_{0.95}$ equal to 2.015 was adopted.

The design value of the longitudinal shear strength of a composite slab, $T_{u, R d}$, is given by the following equation:

$\tau_{u, R d}=\frac{\tau_{u, R k}}{\gamma_{s l}}$

where $V_{s l}$ is the partial factor for design shear resistance of a composite slab.

\subsection{Partial factor design shear resistance}

The EUROCODE 4 [4] recommends that the initial slip load $\left(V_{\text {des }}\right)$ in tests should be greater than 1.2 times the design service load $\left(V_{s}\right)$, as shown in Eq. (22).

$V_{\text {des }} \geq 1.2 V_{s}$

The design service load can be calculated by the following equation: $V_{s} \geq \frac{V_{l, R}}{\gamma_{s l} \gamma_{c}}$

where $V_{I, R}$ is the nominal value of the resistance to shear, and $\gamma_{c}$ is the partial factor for concrete taken as equal to 1.4 .

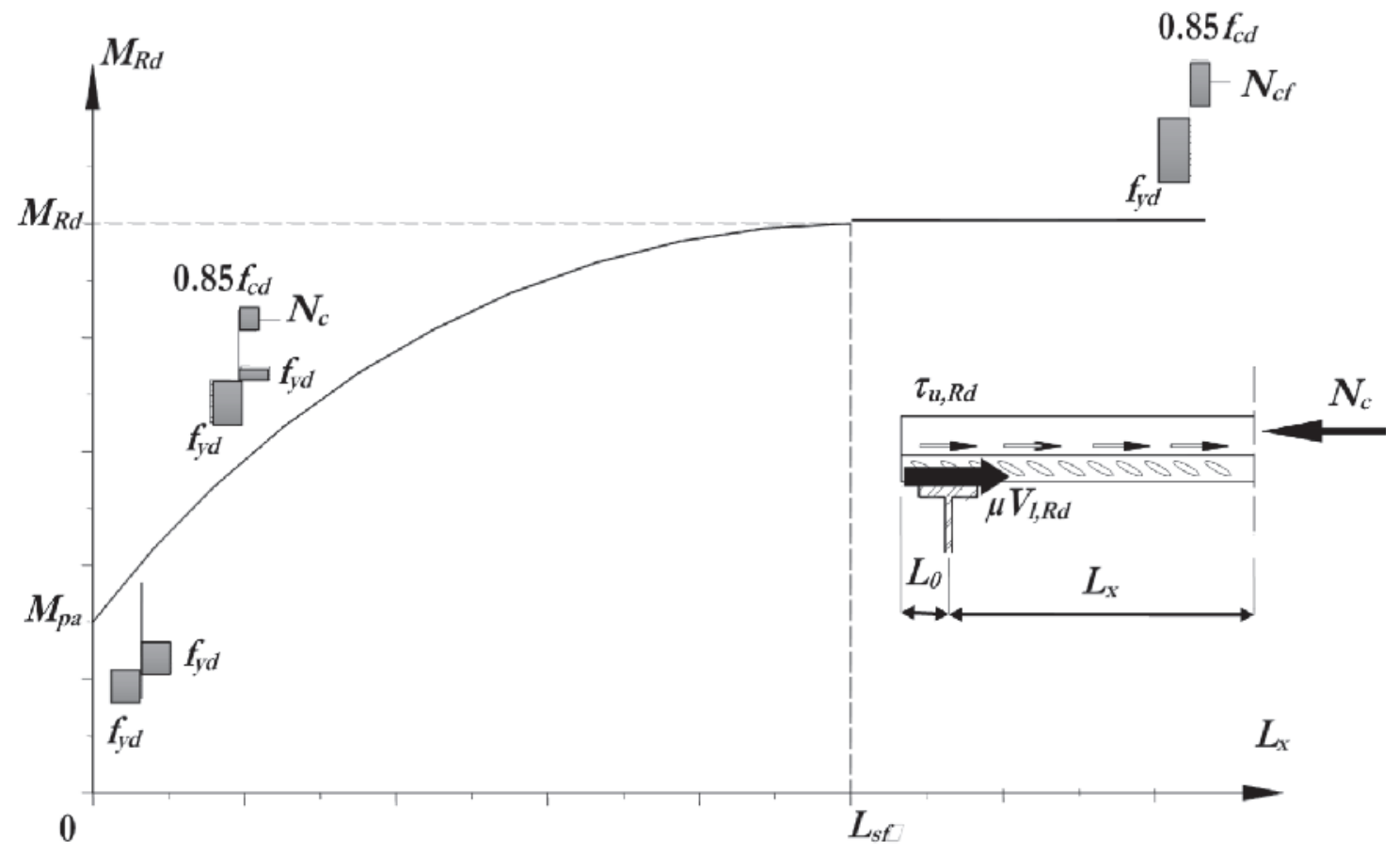

Figure 12

Design partial interaction diagram 
Substituting Eq. (23) in Eq. (22) we obtain the following equation:

$\gamma_{s l} \geq \frac{1.2 V_{l, R}}{\gamma_{c} V_{d e s}}$

The value of $\gamma_{s^{\prime}}$ determined for this composite slabs system, considering influence of friction at the supports, was equal to 1.60

\subsection{Verification of the longitudinal shear resistance}

The verification of the longitudinal shear resistance is conducted through the partial interaction diagram, as shown in Figure 12.

After the determination of the design value of longitudinal shear strength and the support reaction for each specimen, the force transferred to the concrete, $N_{c}$, in any section distant $\left(L_{x}\right)$ from the end can be determined by Eq. (25).

$N_{c}=b \tau_{u, R d} L_{x}+\mu V_{l, R d}$

Substituting the value of $N_{c}$ in Eqs. (1) to (4) and using design values, determine the design partial interaction diagram, $M_{R d}$ versus $L_{x}$, where $M_{R d}$ is the design value of the resistance moment of a composite section.

The length $L_{s f}$ is given by the following equation:

$L_{s f}=\frac{N_{c f}-\mu V_{l, R d}}{b \tau_{u, R d}}$

The verification procedure is illustrated in Figure 13 for two slabs with different types of loading and spans.

For $L_{x} \geq L_{s f}$ the shear connection is full, so the bending resistance (flexural failure) is critical. If $L_{x}<L_{s f}$ the shear connection is partial, so the longitudinal shear resistance is critical. At any cross-section, the design bending moment $M_{S d}$ should not exceed the design resistance $M_{R d^{\prime}}$

\subsection{Comparative analysis}

Figures 14 and 15 show the results of the nominal shear resistance obtained in the tests and the characteristic shear resistance obtained by the PSC method with friction and without friction, as studied by Costa [19].

Analyzing Figures 14 and 15, it can be observed that the results obtained for the resistances by the PSC method, with and without friction, are below the test values. For the thickness of $0.8 \mathrm{~mm}$, in both cases a maximum reduction of $9 \%$ occurred in relation to the test results. For the thickness of $0.95 \mathrm{~mm}$, maximum reductions of $5 \%$ and $13 \%$ occurred, respectively, with and without friction. These results indicate safe values and consistent with the statistical model presented in section 4.4 .

It can also be observed that, for short shear spans, the results of the PSC method, which explicitly consider the influence of friction, presented values of $5.7 \%$ and $10.5 \%$ higher than the results obtained without friction, for thicknesses of $0.80 \mathrm{~mm}$ and $0.95 \mathrm{~mm}$, respectively, indicating the importance of this influence. For long shear spans, the results obtained with and without friction were practically the same for both thicknesses, indicating the small influence of the friction. Therefore, it can be concluded that the influence of the friction is significant for determining the longitudinal shear strength of composite slabs.

\section{Example}

Using the steel sheeting Deck-60 for a composite slab with width (b) of one meter, it will be determine the characteristic value of the maximum superimposed load that can be applied on the
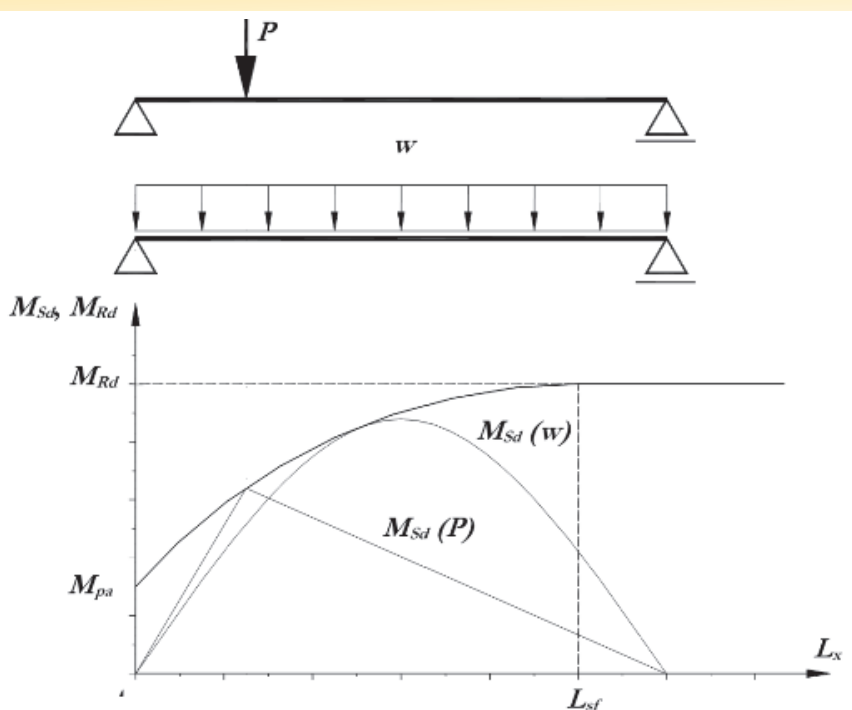

Figure 13

Verification procedure

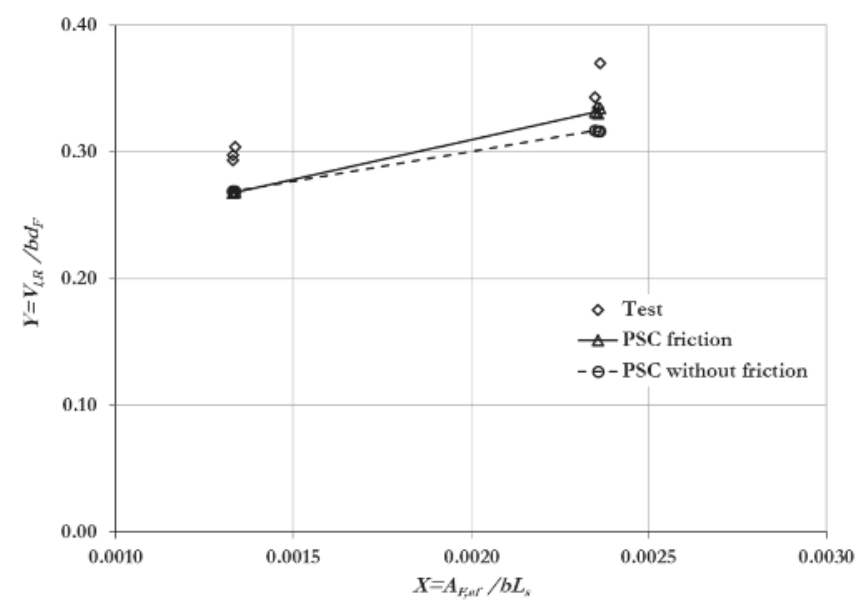

Figure 14

Characteristic shear resistance of specimens of the groups 01 and $02(\dagger=0.80 \mathrm{~mm})$

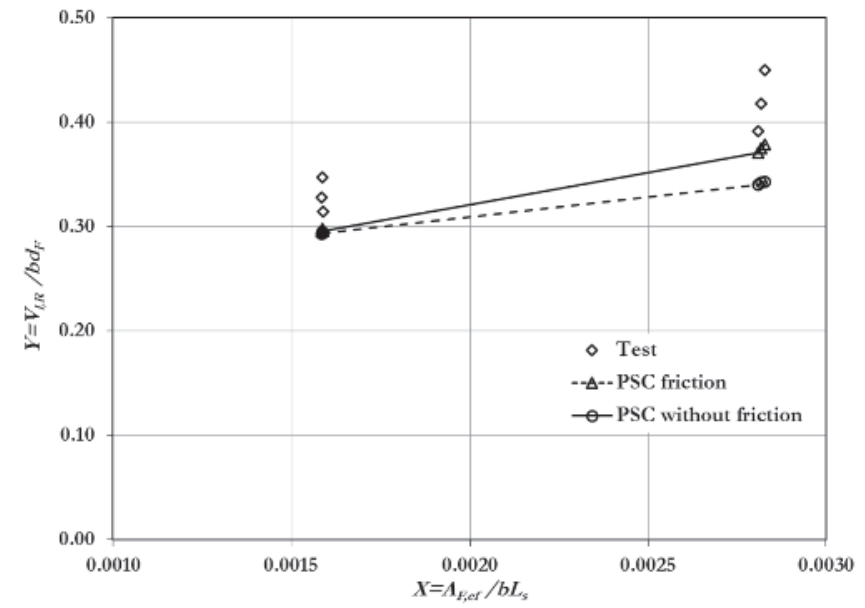

Figure 15

Characteristic shear resistance of specimens of the groups 03 and $04(\dagger=0.95 \mathrm{~mm})$ 
composite slab considering the longitudinal shear strength, both with friction and without friction, from Eq. (1). Three distinct cases of loading as shown in Figures 16, 17 and 18, will be analysed:

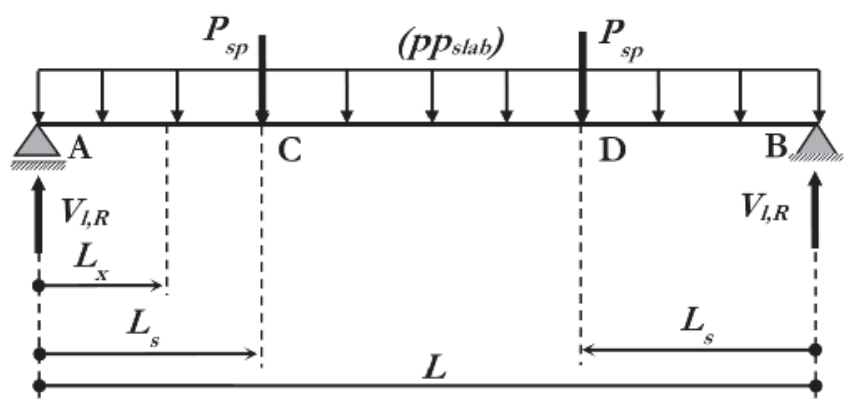

Figure 16

Two concentrated loads

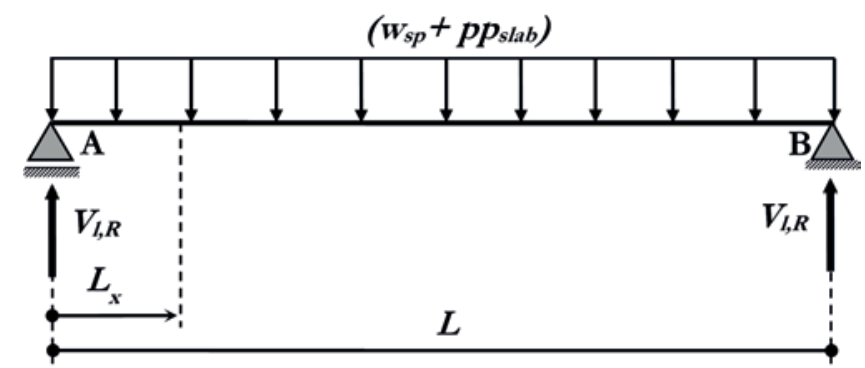

Figure 17

Uniformly distributed load

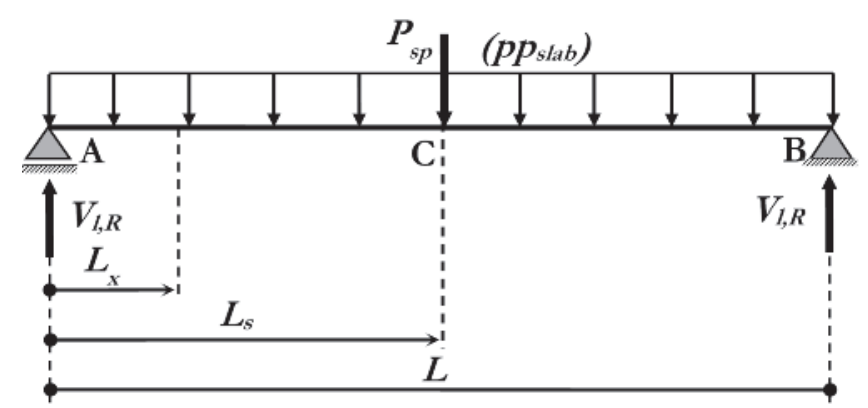

Figure 18

One concentrated load a) two concentrated loads $\left(P_{s p}\right)$ applied in line equidistant from the supports, with the shear span $L_{s}=450 \mathrm{~mm}$;

b) uniformly distributed load $\left(w_{s p}\right)$;

c) one concentrated load $\left(P_{s p}\right)$ applied in line in the mid-span. where $w_{s p}$ is the characteristic value of the maximum superimposed distributed load. $P_{s p}$ is the characteristic value of the maximum superimposed concentrated load. $V_{I, R}$ is the characteristic value of the longitudinal shear resistance, and $p p_{\text {slab }}$ is the dead load of the composite slab.

The following are the data of the composite slab (see Figures 2 and 8):

Length of the slab, $L=2500 \mathrm{~mm}$;

Width of the slab, $b=1000 \mathrm{~mm}$;

Nominal thickness of the sheet, $t=0.80 \mathrm{~mm}$;

Depth of the sheet, $h_{F}=60 \mathrm{~mm}$;

Effective area of the sheet, $A_{F, e f}=1060.47 \mathrm{~mm}^{2} / \mathrm{m}$;

- Nominal value of the yield strength of structural steel, $f_{y}=280$ $\mathrm{N} / \mathrm{mm}^{2}$;

- Modulus of elasticity of steel, $E_{a}=200000 \mathrm{~N} / \mathrm{mm}^{2}$;

Overall depth of the slab, $h_{t}=140 \mathrm{~mm}$;

Distance from the centroidal axis of profiled steel sheeting to top of composite slab, $d_{F}=110 \mathrm{~mm}$;

- Distance from centroidal axis of profiled steel sheeting to bottom of steel deck; $e=30 \mathrm{~mm}$;

Distance from neutral-plastic axis of the profiled steel sheeting to bottom of steel deck, $e_{p}=30 \mathrm{~mm}$;

Dead load of composite slab, $p p_{\text {slab }}=0.00276 \mathrm{~N} / \mathrm{mm}^{2}$;

- Characteristic compressive strength of concrete, $f_{c k}=20 \mathrm{~N} / \mathrm{mm}^{2}$;

- Modulus of elasticity of concrete, $E_{c}=21287 \mathrm{~N} / \mathrm{mm}^{2}$;

- Characteristic value of longitudinal shear strength of a composite slab, $T_{u, R k}$ (without friction) $=0.2283 \mathrm{~N} / \mathrm{mm}^{2}, T_{u, R k}$ (friction) $=$ $0.2050 \mathrm{~N} / \mathrm{mm}^{2}$.

Table 4 presents the results of the characteristic maximum superimposed loads obtained by PSC method, with friction and without friction.

The case (a) of two applied concentrated loads corresponds to the test conditions of specimen $02 \mathrm{~A}$, according to Table 1 , whose maximum test load is equal to $32.67 \mathrm{kN}$ for $L$ equal to $1000 \mathrm{~mm}$. The result with friction presented in Table 4 for this case is below the test value in $12.5 \%$, indicating the consistency of the method, as shown in Figure 14.

In all cases shown in Table 4 an increase in longitudinal shear resistance was observed when considering the influence of the

\section{Table 4}

Results obtained by the PSC method

\begin{tabular}{|c|c|c|c|c|}
\hline \multirow[b]{2}{*}{ Load cases } & \multirow[b]{2}{*}{ Maximum loads } & \multicolumn{2}{|c|}{ Method } & \multirow{2}{*}{$\begin{array}{c}\text { Comparison } \\
\text { (PSC** - PSC*) } \\
\text { PSC** } \\
(\%)\end{array}$} \\
\hline & & PSC* & PSC $* *$ & \\
\hline Two concentrated loads & $P_{s p}(k N)$ & 24.34 & 28.57 & 14.80 \\
\hline Distributed load & $\mathrm{w}_{\mathrm{sp}}\left(\mathrm{kN} / \mathrm{m}^{2}\right)$ & 25.35 & 27.19 & 6.77 \\
\hline One concentrated load & $\mathrm{P}_{\mathrm{sp}}(\mathrm{kN})$ & 39.44 & 41.00 & 3.80 \\
\hline
\end{tabular}


friction, as expected. It is also verified that this increase is greater the smaller the shear span $\left(L_{s}\right)$ considered, indicating the consistency of the PSC method.

Figure 19 shows the nominal resistance moment curve $\left(M_{R}\right)$ obtained through the partial interaction diagram according to the procedure presented in section 4.6 and the applied nominal bending moment curve $\left(M_{S}\right)$ for two concentrated loads. These curves illustrate the procedure for checking the shear strength of a composite slab. In this case the applied bending moment curve, $M_{S}$, is tangential to the nominal resistance moment curve, MR, indicating a safe solution, where $M_{S} \leq M_{R}$. The point at which $M_{S}$ and $M_{R}$ are equal correspond to the value of the shear span, $L_{s f}$ that is smaller than the length $L_{s f}$. The length $L_{s f}$ defines the value from which the shear connection is complete and the failure occurs by bending. Therefore, it was concluded that, in this case, the shear connection is partial, indicating that the longitudinal shear resistance is critical.

\section{Conclusion}

The partial shear connection method (PSC) is an alternative for the " $m$ $\mathrm{k}$ " method for checking the longitudinal shear resistance, allowing the theoretical evaluation of the contribution of the friction of the region at the support and of end anchorage in the longitudinal shear resistance. Tests were conducted at the Structural Engineering Laboratory of Federal University of Minas Gerais (UFMG) on 12 specimens of composite slabs varying shear spans and thickness of decking with embossments in a "V" shape. Deflections, end slips and steel strains were measured, allowing the analysis of the behavior of the composite slab system and the determination of its failure mode by shear bond.

These analyses were evaluated through the PSC method, taking into account the influence of the friction of the region of support in the longitudinal shear resistance, according to EUROCODE 4 [4]. The EUROCODE 4 [4] recommends a partial factor for design shear resistance $\left(\gamma_{s}\right)$ equal to 1.25 for both methods, "m-k" and PSC. However, it is recommended that for the calculation of the deflections, generally no account need be taken of end slip if the initial slip load in tests exceeds 1.2 times the design service load. Therefore, the value of $\gamma_{s l}$ obtained for this composite slab system, considering influence of friction at the supports, was determined to be equal to 1.60 through the PSC method.

The analysis showed that the PSC method, considering the influence of the friction in the support, leads to consistent results in relation to the tests and in the determination of the longitudinal shear resistance. It was also concluded that the influence of the friction in the support is significant for the determination of the longitudinal shear strength of composite slabs, the smaller the shear span, $L_{s}$. The example presented using the expressions and calculations from the PSC method, incorporating the friction demonstrated the efficiency of the method in the evaluation of the longitudinal shear resistance.

\section{Acknowledgments}

The authors are grateful to the CAPES - Coordination for the Improvement of Higher Education Personnel and CNPq - Brazilian National Council for Scientific and Technological Development, for their support to carry out this research.

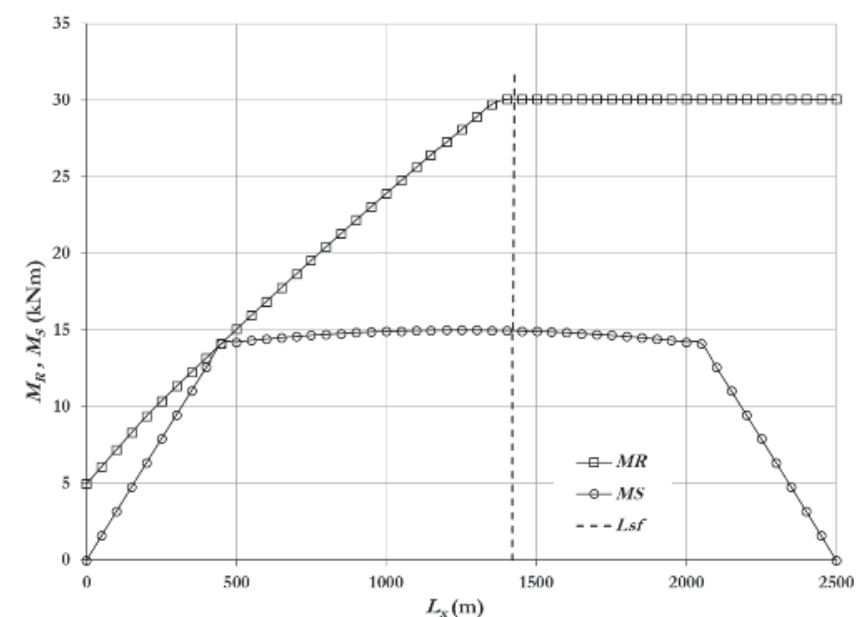

Figure 19

Curves of nominal resistance moment, $M_{R^{\prime}}$ and of applied nominal bending moment, $\mathrm{M}_{\mathrm{S}^{\prime}}$ for the verification of the longitudinal shear resistance of two concentrated loads

\section{References}

[1] VELJKOVIC', M. Behaviour and Resistance of Composite Slabs. Experiments and Finite Element Analysis. Doctoral Thesis - Luleå University of Technology, Tuleå, Swedish, 1996.

[2] SCHUSTER R.M. Strength and behaviour of the P-2430 $12 \mathrm{HB}$, composite slab system (normal weight concrete). Department of civil engineering, university of waterloo. Report no. WRI 110-12-02. Canada; 1984.

[3] ANSI/ASCE 3-91. Standard for the structural design of composite slabs, American society of civil engineers, 1992.

[4] EN 1994-1-1. Design of Composite Steel and Concrete Structures, Part 1.1, General rules and rules for building, CEN - European Committee for Standardization, 2004.

[5] CSSBI S2. Criteria for the testing of composite slabs. Canadian sheet steel building institute. Willodale, revised. Ontario. Canada, 2008.

[6] JOHNSON R.P. and Shepherd A.J. Resistance to longitudinal shear of composite slabs with longitudinal reinforcement. Journal of Constructional Steel Research; 82: 190-194, 2013.

[7] WRIGHT H.D, EVANS H.R, HARDING P.W. The use of profiled steel sheeting in floor construction. Journal of Constructional Steel Research; 7: 279-95, 1987.

[8] TENHOVUORI A.I and LESKELA M.V. Longitudinal shear resistance of composite slab. Journal of Constructional Steel Research; 46(1-3):228, 1998.

[9] MELO C.B.F. Análise do comportamento e da resistência do sistema de lajes mistas. Dissertação de Mestrado. Programa de pós-graduação em engenharia de estruturas. Universidade Federal de Minas Gerais, Belo Horizonte. Brasil; 141 p. 1999.

[10] MARIMUTHU V., SEETHARAMAN S., JAYACHANDRAN S.A., CHELLAPPAN A., BANDYOPADHYAY T.K. and DUT- 
TA D. Experimental studies on composite deck slabs to determine the shear-bond characteristic $(m-k)$ values of the embossed profile sheet. Journal of Constructional Steel Research; 63:791-803, 2007.

[11] CIFUENTES $\mathrm{H}$ and MEDINA F. Experimental study on shear bond behavior of composite slabs according to Eurocode 4 . Journal of Constructional Steel Research; 82: 99-110, 2013.

[12] JOHNSON R.P. Composite structures of steel and concrete - beams, slabs, columns and frames for buildings. Blackwell Scientific Publications. Vol. 01, $2^{\mathrm{a}}$ ed. Oxford, 1984.

[13] VELJKOVIC' M. Development of a New Sheeting Profile for Composite Floor. Experimental Study and Interpretation Research Report, Division of Steel Structures, Luleå University of Technology, Tuleå, Swedish, 1993.

[14] TENHOVUORI A. Parameters and definitions for classifying the behaviour of composite slabs. Composite Construction in Steel and Concrete III. Proceedings of an engineering foundation conference. ASCE - American Society of Civil Engineers. New York, 1996.

[15] CALIXTO J.M. and Lavall A.C. Behavior and strength of composite slabs with ribbed decking. Journal of Constructional Steel Research; 46(1-3):211-2, 1998.

[16] SOUZA NETO A.S. Análise do comportamento e da resistência de um sistema de lajes mistas com ancoragem de extremidade com considerações sobre a fôrma de aço isolada e o atrito nos apoios. Dissertação de Mestrado. Programa de pós-graduação em engenharia de estruturas. Universidade Federal de Minas Gerais. Belo Horizonte. Brasil, 2001.

[17] BODE, H. and Minas, F. Composite Slabs with and without end Anchorage under Static and Dynamic Loading. Composite Construction - Conventional and Innovative, IABSE Conference Report, pp. 265-270, 1997.

[18] EN 1990. Basic Structural Design. CEN - European Committee for Standardization, 2002.

[19] COSTA R.S. Análise de um sistema de lajes mistas considerando a influência do atrito dos apoios e a avaliação do momento de inércia efetivo. Dissertação de Mestrado. Programa de pós-graduação em engenharia de estruturas. Universidade Federal de Minas Gerais. Belo Horizonte. Brasil. 193p. 2009. 